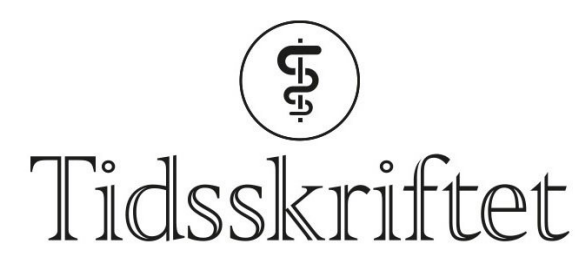

DEN NORSKE LEGEFORENING

\title{
Ole Jakob Johansen
}

MINNEORD

TORSTEIN VIK

ELISABETH SELVAAG

KJELL ̊̊. SALVESEN

RUNA HEIMSTAD

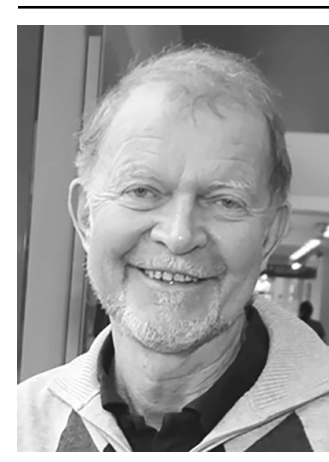

Ole Jakob Johansen, født 1944, døde 25. september 2017, 73 år gammel, etter flere år med alvorlig sarkoidose. Med ham er en faglig solid kollega og en omsorgsfull medarbeider gått bort.

Ole Jakob vokste opp på Møllenberg i Trondheim, som den eldste av tre brødre. Han studerte medisin i Oslo og gjennomførte turnustjenesten i Kristiansund og på Averøy. Her traff han Ingebjørg, som han siden holdt sammen med.

I 1975 flyttet de til Trondheim, der Ole Jakob ble spesialist i pediatri. Han arbeidet som overlege ved Barne- og ungdomsklinikken, på Kvinneklinikken og på Orkdal sjukehus frem til sykdommen tvang ham til å pensjonere seg i 2012. Den første tiden arbeidet han tett sammen med professor Peter Johan Moe om barn med kreft, senere konsentrerte han seg om nyfødtmedisinen. I nær 20 år undersøkte han praktisk talt alle nyfødte i Sør-Trøndelag. Like lenge hadde han hovedansvaret for den medisinske oppfølgingen av barn med Downs syndrom.

Han så det som en naturlig del av sin kliniske virksomhet å delta i forskning og undervisning, og han var medforfatter på flere vitenskapelige artikler. Mange av disse inngikk i yngre kollegers doktoravhandlinger. Han deltok også aktivt i undervisningen av legestudenter og spesialistkandidater og av annet helsepersonell. Han ble derfor også spesielt verdsatt av sykepleiere, barnepleiere og jordmødre. I 2012 fikk han Kongens 
fortjenstmedalje.

Ole Jakob var en ivrig friluftsmann, jeger og fisker, gjerne med utgangspunkt i hytta på Nerskogen eller feriestedet på Averøya. Han var motorsykkelentusiast og fartet Europa rundt i yngre år. På sine eldre dager kjøpte han en veteransykkel (BMW) som han benyttet for å komme seg frem og tilbake til Orkdal sjukehus. Sin interesse for astronomi dokumenterte han under turnustjenesten ved å bygge sin egen stjernekikkert med materiale fra et mekanisk verksted i Kristiansund. Sjøfartshistorie var et annet interessefelt, han leste blant annet bøkene til Patric O’Brian på autentisk historisk engelsk.

Men først og fremst var Ole Jakob en tilstedeværende og engasjert far for sine to døtre og bestefar for sine tre barnebarn. I disse dager går våre tanker til Ingebjørg, døtrene og barnebarna og den øvrige familie. I den vanskeligste sykdomsperioden ga Ole Jakob sterkt uttrykk for hvor glad og heldig han var som hadde sin nærmeste familie rundt seg.

Vi sørger over å ha mistet en god venn og kollega.

På vegne av venner og kolleger

Publisert: 12. desember 2017. Tidsskr Nor Legeforen. DOI: 10.4045/tidsskr.17.0915

(C) Tidsskrift for Den norske legeforening 2020. Lastet ned fra tidsskriftet.no 